\title{
AKAD MUZARA'AH PERTANIAN PADI DALAM PERSPEKTIF HUKUM EKONOMI SYARIAH
}

\author{
Achmad Otong Busthomi, Edy Setyawan dan Iin Parlina \\ Fakultas Syari'ah dan Ekonomi Islam \\ Institut Agama Islam Negeri Syekh Nurjati Cirebon \\ e-mail: tomibust@yahoo.com,edysetyawano@yahoo.com \\ dan iinparlinna@gmail.com
}

\begin{abstract}
The landless farmer chooses to enter into a muzara'ah coorporation with the landowner according to custom, without knowing whether the agreement is appropriate or not with sharia economic law. As practice in the Gebang Kulon village, the agreement there is a continuous deviation resulting in the cancellation. Seeing the problem, the writer feels the need to study more deeply based on the review of Sharia economic law. The method used in this research is to use qualitative by utilizing the descriptive approach of Sharia economic law. Technique of collecting date that is done observation, interview and documentation. From the research results obtained the agreement is done orally on the basis of hel and trust. The agreement is termed maro, where the landowner and the tiller agre the result will be devided into two with the provisions of the landowner hand over land and production capital such as paddy and other, seeds while the cultivators provide tools and manpower. According to the review of Sharia economic law, the muzara'ah is done based on the terms and conditions, so that if the conditions of muzara'ah are fulfilled then the agreement is valid.
\end{abstract}

Keywords: Muzara'ah, Maro, Sharia Economic Law.

\begin{abstract}
Abstrak
Petani yang tidak memiliki lahan memilih melakukan kerjasama muzara'ah dengan pemilik lahan sesuai adat, tanpa mengetahui apakah perjanjiannya sesuai atau tidak dengan hukum ekonomi Syariah. Sebagaimana dalam praktiknya di desa Gebang Kulon, kesepakatan akadnya terdapat penyimpangan yang berkelanjutan sehingga terjadi pembatalan. Melihat permasalahan tersebut, penulis merasa perlu mengkaji lebih dalam berdasarkan perspektif hukum ekonomi Syariah. Metode yang digunakan dalam penelitian ini adalah kualitatif dengan memanfaatkan pendekatan deskriptif kualitatif hukum ekonomi Syariah. Teknik pengumpulan data yang dilakukan yaitu observasi, wawancara dan dokumentasi. Dari hasil penelitiannya diperoleh bahwa akad dilakukan secara lisan atas dasar tolong menolong dan kepercayaan. Perjanjian itu diistilahkan dengan maro, dimana pemilik dan penggarap sepakat hasilnya akan dibagi dua dengan ketentuan pemilik menyerahkan lahan dan modal produksi seperti bibit padi dan lainnya, sedangkan penggarap menyediakan alat dan tenaga. Menurut hukum ekonomi Syariah, akad muzara'ah dilakukan berdasarkan rukun dan syarat, sehingga apabila syarat-syarat muzara'ah terpenuhi maka akadnya sah.
\end{abstract}

Kata Kunci: Muzara'ah, Maro, Hukum Ekonomi Syariah. 


\section{PENDAHULUAN}

Islam mensyariatkan akad sebagai tindakan hukum berdasarkan kehendak dua pihak. Hal itu juga dikemukakan oleh Wahbah azZuhaili dalam al-Figh al-Islami wa Adillatuh. ${ }^{1}$ Kehendak dua pihak itu terkait isi kesepakatan dalam akad yang dilakukan. Dalam akad terdapat ijab dan qabul yang termasuk rukun agar pelaksanaan akad hukumnya sah dan tidak ada faktor paksaan dari pihak manapun. Menurut Kompilasi Hukum Ekonomi Syariah, yang dimaksud dengan akad adalah kesepakatan dalam suatu perjanjian antara dua pihak atau lebih untuk melakukan dan atau tidaknya perbuatan hukum tertentu. ${ }^{2}$ Perbuatan hukum merujuk kepada tindakan atau suatu kegiatan yang diawali dengan adanya perjanjian, seperti kerjasama dalam bidang apapun. Kerjasama merupakan watak masyarakat ekonomi menurut ajaran Islam. Kerjasama tersebut harus tercermin dalam semua kegiatan ekonomi. ${ }^{3}$

Muzara'ah adalah suatu cara untuk menjadikan tanah pertanian menjadi produktif dengan bekerja sama antara pemilik dan penggarap dalam memproduktifkannya, dan hasilnya dibagi di antara mereka berdua dengan perbandingan (nisbah) yang dinyatakan dalam perjanjian atau berdasarkan 'urf (adat kebiasaan). ${ }^{4}$ Dimana pemilik lahan yang menyediakan lahan dan bibit/benih dan modal produksi lainnya untuk penggarap, sedangkan penggarap yang memiliki alat dan kemampuan bekerja menjaga, memelihara dan menggarap lahan tersebut agar dapat memperoleh hasil panen sesuai waktu tertentu. Keuntungannya dibagi sesuai

\footnotetext{
${ }^{1}$ Syamsul Anwar, Hukum Perjanjian Syariah: Studi tentang Teori Akad dalam Fikih Muamalat (Jakarta: Rajawali Pers, 2010), 73.

${ }^{2}$ Mardani, Fiqh Ekonomi Syariah: Fiqh Muamalah (Jakarta: Kencana, 2012), 72.

${ }^{3}$ Muhammad Daud Ali, Sistem Ekonomi Islam: Zakat dan Wakaf (Jakarta: UI Press, 1988), 15.

${ }^{4}$ Ahmad Wardi Muslich, Fiqh Muamalat (Jakarta: Amzah, 2013), 392.
}

dengan kesepakatan kedua belah pihak, yakni setengah-setengah, sepertiga, atau seperempat.

Pertanian di Gebang Kulon tanahnya subur. Wilayah pertaniannya terletak di dusun 04, dusun 05, dan dusun 06. Tanaman yang ditanam adalah padi dan jagung. Kelompok petaninya diistilahkan dengan Gapoktan Sri Rahayu (Gabungan Kelompok Petani Padi). Petani yang menggarap, ada yang menggarap sawahnya sendiri dan mempercayai orang lain untuk menggarap sawah dengan sistem perjanjian bagi hasil. Perjanjian kerjasama yang dilakukan untuk mengambil manfaat dari hasil panen guna memenuhi kebutuhan hidup.

Perjanjian yang dilakukan di kalangan masyarakat petani desa Gebang Kulon pada umumnya dilakukan dengan tidak tertulis atau hanya secara lisan. Dimana saat pemilik lahan mempercayai penggarap untuk menggarap lahannya sampai mendapatkan hasil panen. Bagi hasil yang disepakati oleh masyarakat petani dalam akad umumnya dikenal dengan sebutan maro, mertelu dan mrapat. Di desa Gebang Kulon, menggunakan istilah maro dimana hasil panen akan dibagi dua. Hasilnya dibagi bersama sesuai dengan kesepakatan. Hal tersebut sering menimbulkan masalah yang biasanya terjadi apabila pemilik ataupun penggarap tidak menepati perjanjian atas kesepakatan yang telah dibuat sebelumnya, sehingga salah satu dari mereka merasa dirugikan.

Kasus yang timbul adalah kelalaian petani ketika menggarap sawah, terkadang ada pihak penggarap sawah yang tidak sungguh-sungguh dalam penggarapannya. Seperti saat sudah memasuki masa pemupukan, akan tetapi penggarap tidak memberikan pupuk. Masalah itu menyebabkan tanaman menjadi layu ataupun mati sebelum panen, sehingga kualitas hasil panen menjadi buruk. Masalah yang berkelanjutan sehingga mengakibatkan pembatalan oleh pemilik. Untuk itu maka penulis merasa perlu untuk mengkaji lebih 
dalam lagi mengenai 1) Bagaimana akad muzara'ah pertanian padi di desa Gebang Kulon Cirebon? 2) Bagaimana akad muzara'ah pertanian padi di desa Gebang Kulon Cirebon dalam perspektif Hukum Ekonomi Syariah?

\section{LITERATURE REVIEW}

Penelitian tentang akad muzara'ah bukanlah suatu yang baru. Meskipun demikian, ditemukan perbedaan permasalahan penelitian yang secara spesifik dikaji dari segi hukum ekonomi syariah. Berikut beberapa karya yang terdokumentasikan terkait penelitian yang dikaji, yaitu pertama, penelitian yang dilakukan oleh Erick Prasetyo Agus. ${ }^{5}$ Penelitian ini memfokuskan terhadap peningkatan produktivitas kerja petani yang ditinjau dari segi sistem bagi hasil muzara'ah. Menurutnya, sistem bagi hasil yang dilakukan masyarakat petani Pakan Rabaa menggunakan sistem pemilik lahan dan penggarap, mampaduai, dan buruh tani. Pada umumnya sistem mampaduai yaitu setengah-setengah atas dasar kepercayaan. Produktivitas kerja petani yang ditinjau dari sistem muzara'ah memiliki keterkaitan yang rendah. Karena keduanya tidak saling mempengaruhi dimana bagi hasil yang diperoleh tidak signifikan dengan peningkatan kinerja petani yang menggarap, dan diketahui hasilnya dari 100 orang petani.

Kedua, penelitian yang dilakukan oleh Unggul Priyadi dan Jannahar Saddam ashShidiqie. ${ }^{6}$ Penelitian ini memfokuskan pada aspek bagi hasil pertanian lahan sawah dikaitkan dengan muzara'ah, musaqah dan mukhabarah. Menurutnya, praktik perjanjian bagi hasil lahan sawah di

${ }^{5}$ Erick Prasetyo Agus, "Produktivitas Kerja Petani Ditinjau Dari Sistem Muzara'ah (Studi Pada Desa Pakan Rabaa Kabupaten Solok Selatan Sumatera Barat)", Skripsi (Jakarta: Fakultas Syariah dan Hukum UIN Syarif Hidayatullah, 2008).

${ }^{6}$ Unggul Priyadi dan Jannahar Saddam ashShidiqie, "Pelaksanaan Perjanjian Bagi Hasil Pertanian Lahan Sawah", Millah, Vol. XV, No. 1 (Agustus, 2015): 1-15. kecamatan Gamping telah memenuhi syarat hukum Islam, karena adanya ijab dan qabul yang dipenuhi oleh pemilik dan penggarap, serta adanya manfaat dari hasil kerja petani. Meskipun perjanjian secara umumnya dilakukan dengan lisan atas dasar kepercayaan, namun dalam Islam tidak terdapat penjelasan yang menyatakan kerjasama dalam pertanian harus dilakukan secara tertulis. Perjanjian tersebut tetap sah karena memenuhi syarat-syarat dalam hukum Islam.

Dan ketiga, penelitian yang dilakukan oleh Sony Hendri. ${ }^{7}$ Penelitian ini memfokuskan kepada pengaruh muzara'ah terhadap tingkat pendapatan masyarakat. Praktik bagi hasil perkebunan kelapa sawit di desa Kota Garo Kecamatan Tapung Hilir Kabupaten Kampar dilakukan dengan sistem sepertiga dan separuh dari hasil panen. Menurutnya, aplikasi akadnya batal karena seharusnya bentuk perjanjiannya tertulis. Dan bagi hasilnya tidak sesuai dengan Hukum Islam, karena pemilik kebun tidak ingin mengetahui pengeluaran dari penggarap sehingga setelah dihitung penggarap mengalami kerugian, baik keuntungan maupun waktu dan tenaga.

Dari ketiga topik penelitian yang telah dipaparkan di atas, ternyata permasalahan yang dikaji tidak memfokuskan kepada secara umum akad muzara'ah dalam perspektif hukum ekonomi syariah. Melainkan dengan mengaitkan muzara'ah dengan tingkat produktivitas dan pendapatan petani. Disini letak perbedaan studi ini dengan studi-studi sebelumnya. Dengan melakukan penelitian ini diharapkan dapat memberikan pengembangan bagi peneliti selanjutnya.

\footnotetext{
${ }^{7}$ Sony Hendri, "Sistem Bagi Hasil Perkebunan Kelapa Sawit Ditinjau Menurut Perspektif Hukum Islam (Studi Kasus di Desa Kota Garo Kecamatan Tapung Hilir Kabupaten Kampar)", Skripsi (Riau: Fakultas Syariah dan Ilmu Hukum UIN Sultan Syarif Kasim, 2013).
} 


\section{METODOLOGI PENELITIAN}

Jenis penelitian yang digunakan adalah penelitian lapangan (field research). Penelitian lapangan merupakan penelitian yang dilakukan dalam kehidupan sehari-hari atau kehidupan yang sebenarnya. Ide penting dalam penelitian lapangan ini adalah peneliti berangkat untuk mengadakan pengamatan terhadap suatu fenomena dalam suatu keadaan alamiah. Pada penelitian ini peneliti mengamati fenomena yang terjadi dalam praktik akad muzara'ah pertanian padi di desa Gebang Kulon Cirebon pada bulan April-Mei 2018 dengan membuat catatan yang memuat hasil penelitian.

Metode yang digunakan dalam penelitian ini adalah metode kualitatif, yaitu peneliti bermaksud untuk memahami fenomena tentang apa yang dialami oleh subjek penelitian. ${ }^{8}$ Istilah penelitian kualitatif menurut Kirk dan Miller mendefinisikan bahwa metodologi kualitatif adalah tradisi tertentu dalam ilmu pengetahuan sosial yang secara fundamental bergantung pada pengamatan terhadap manusia. Penelitian kualitatif secara umum digunakan untuk penelitian tentang kehidupan masyarakat, aktivitas sosial dan lain-lain. ${ }^{9}$

Pendekatan penelitian ini adalah studi kasus yang termasuk ke dalam format deskriptif kualitatif. Format ini cirinya memusatkan pada suatu fenomena, dan memungkinkan memperoleh data yang amat mendalam bahwa kedalaman data yang menjadi pertimbangan dalam penelitian model ini. Penelitian ini bersifat mendalam dan menusuk sasaran penelitian, tentunya untuk mencapai maksud dan tujuan peneliti membutuhkan waktu yang relatif lama. ${ }^{10}$ Pada praktiknya, hal ini dilakukan untuk

${ }^{8}$ Lexy J. Moleong, Metode Penelitian Kualitatif (Bandung: Remaja Rosdakarya, 2014), 2627.

${ }^{9}$ Pupu Saeful Rahmat, "Penelitian Kualitatif", Equlibrium, Vol. 5 (Juni, 2009): 2.

${ }^{10}$ Burhan Bungin, Penelitian Kualitatif: Komunikasi, Ekonomi, Kebijakan Publik, dan Ilmu Sosial Lainnya (Jakarta: Kencana, 2007), 68-69. mengetahui pandangan hukum ekonomi syariah terhadap praktik praktik akad muzara'ah pertanian padi di desa Gebang Kulon Cirebon.

Sumber data yang diperlukan adalah data primer dan data sekunder. Data primer didapatkan melalui wawancara dengan informan diantaranya petani penggarap dan pemilik lahan. Adapun data sekunder yang digunakan di sini yaitu, skripsi, jurnal, dan website yang berkaitan dengan akad muzara'ah, serta data dari kantor Balai Desa Gebang Kulon.

Teknik pengumpulan data yang digunakan adalah wawancara, observasi dan dokumentasi. Pertama, Wawancara merupakan interaksi bahasa yang berlangsung antara dua orang dalam keadaan saling berhadapan, yakni yang melakukan wawancara meminta informasi kepada orang yang diteliti berdasarkan pendapat dan keyakinannya. ${ }^{11}$ Wawancara yang digunakan adalah wawancara semi terstruktur dimana pewawancaralah yang lebih mengarahkan pembicaraan. Pewawancara tidak mengajukan persoalan berdasarkan daftar pertanyaan yang telah disiapkan. Topik yang menentukan arah pembicaraan. Jenis ini lebih terarah dan disebut dengan istilah wawancara format fokus. ${ }^{12}$ Dalam hal ini peneliti mewawancarai beberapa informan yang aktif melakukan praktik akad muzara'ah seperti petani penggarap dan pemilik lahan. Kedua, Observasi merupakan upaya untuk mengamati dan mendokumentasikan hal-hal yang terjadi selama tindakan berlangsung. Metode observasi yang dilakukan adalah observasi terbuka, yaitu pencatatan semua kejadian dalam kegiatan penelitian; dan observasi terfokus, yaitu teknik pengumpulan data yang ingin diperoleh

\footnotetext{
${ }^{11}$ Emzir, Analisis Data: Metodologi Penelitian Kualitatif (Jakarta: Rajawali Pers, 2012), 49-50.

${ }^{12}$ Suwartono, Dasar-dasar Metodologi Penelitian (Yogyakarta: Andi, 2014), 50.
} 
sudah dituangkan dalam format tertentu. ${ }^{13}$ Teknik observasi yang dilakukan dalam penelitian ini dengan cara melakukan pengamatan, mencatat data secara sistematik langsung kepada objek penelitian yaitu pengamatan terhadap kondisi wilayah dan perilaku subjek penelitian. Dan ketiga, Dokumen diartikan sebagai suatu catatan tertulis/gambar yang tersimpan tentang sesuatu yang sudah terjadi. Dokumen merupakan fakta dan data tersimpan dalam berbagai bahan yang berbentuk dokumentasi. Sebagian besar data yang tersedia adalah bentuk surat, laporan, peraturan, catatan harian, biografi, simbol, foto, sketsa dan data yang tersimpan lainnya. Dokumentasi ini untuk memperkuat data yang diambil dari hasil observasi dan wawancara. $^{14}$ Peneliti mencari sumbersumber data yang lain selain wawancara dan observasi yang berkaitan dengan kajian yang dibahas. Seperti misalnya buku-buku yang relevan, laporan kegiatan, foto-foto, dan data yang relevan.

Penelitian ini menggunakan teknis analisis data. Menganalisis data merupakan suatu langkah yang sangat kritis dalam penelitian. Pola analisis yang akan digunakan adalah analisis non-statistik karena jenis data yang dikumpulkan sesuai untuk data deskriptif. Data deskriptif dianalisis menurut isinya, dan analisis semacam ini disebut juga dengan analisis isi (content analysis). ${ }^{15}$ Teknik analisis yang digunakan adalah metode analsis deskriptif yang termasuk dalam penelitian pendekatan kualitatif, dengan mengolah dan mendeskripsikan hasil penelitian dari data yang diperoleh. Sehingga mendapatkan

\footnotetext{
${ }^{13}$ Suryana, Metodologi Penelitian: Model Praktis Penelitian Kuantitatif dan Kualitatif (Bandung: Universitas Pendidikan Indonesia, 2010), 51-53.

${ }^{14}$ Aunu Rofiq Djaelani, “Teknik Pengumpulan Data dalam Penelitian Kualitatif', FPTK IKIP Semarang, Vol. XX, No. 1 (Maret 2013): 88.

${ }^{15}$ Sumadi Suryabrata, Metodologi Penelitian (Jakarta: PT. Raja Grafindo Persada, 1997), 85.
}

kesimpulan yang singkat dan jelas tapi dipahami.

\section{KONSEP DASAR}

Pengertian Akad

Akad berasal dari kata $a l$ - 'aqd, yang berarti mengikat, menyambung atau menghubungkan (ar-rabt). ${ }^{16}$ Dalam Kamus Umum Bahasa Indonesia, definisi perjanjian adalah persetujuan tertulis dengan lisan yang dibuat oleh kedua belah pihak atau lebih yang mana saling sepakat akan melakukan apa yang diperjanjikan itu. ${ }^{17}$ Menurut para ulama fiqh, kata akad didefinisikan sebagai hubungan antara ijab dan qabul sesuai dengan kehendak syariat yang menetapkan adanya pengaruh (akibat) hukum dalam objek perikatan. Akad atau perjanjian dapat diartikan sebagai kemitraan yang terbingkai dengan nilai-nilai syariah. ${ }^{18}$

\section{Muzara'ah dalam Islam}

Secara etimologis, muzara'ah berarti kerjasama di bidang pertanian antara pemilik tanah dengan petani penggarap. Adapun secara terminologis muzara'ah yaitu penyerahan tanah kepada seorang petani untuk digarap dan hasilnya dibagi dua. ${ }^{19}$ Muzara'ah seringkali diidentikkan dengan mukhabarah. Di antara keduanya terdapat sedikit perbedaan yaitu muzara'ah, benih/bibitnya didapat dari pemilik tanah. Sedangkan mukhabarah, benih/bibitnya didapat dari petani penggarap. ${ }^{20}$

Menurut ulama Hanafiyah, muzara'ah adalah akad untuk bercocok tanam dengan sebagian yang keluar dari bumi. ${ }^{21}$ Menurut

\footnotetext{
${ }^{16}$ Syamsul Anwar, Hukum Perjanjian Syariah: Studi tentang Teori Akad dalam Fikih Muamalat, 68.

${ }^{17}$ WJS. Poerwadaminta, Kamus Umum Bahasa Indonesia (Jakarta: Balai Pustaka, 1986), 402 .

${ }^{18}$ Mardani, Hukum Bisnis Syariah, Cet. 1 (Jakarta: Kencana, 2014), 71.

${ }^{19}$ Mardani, Hukum Bisnis Syariah, 145.

${ }^{20}$ Muhammad Syafi'i Antonio, Bank Syariah: dari Teori ke Praktik (Jakarta: Gema Insani Press, 2001), 99.

${ }^{21}$ Hendi Suhendi, Fiqh Muamalah (Jakarta: Rajawali Pers, 2013), 153.
} 
ulama Hanabilah, muzara'ah adalah Penyerahan tanah pertanian kepada seorang petani untuk di garap dan hasilnya dibagi dua. Menurut ulama Syafi'iyah, muzara'ah adalah kerjasama antara pemilik tanah dan penggarap tanah dengan perjanjian bagi hasil yang jumlahnya sesuai kesepakatan bersama, dan benih (bibit) tanaman berasal dari pemilik tanah. ${ }^{22}$ Menurut Malikiyah, muzara'ah adalah Bersekutu dalam akad. ${ }^{23}$

\section{Dasar Hukum Muzara'ah}

Muzara'ah termasuk ke dalam jenis akad tabarru atau akad sosial, dimana tujuan melakukan akad tersebut adalah tolong menolong kepada yang membutuhkan. Dalam muzara'ah harus mempertimbangkan faktor-faktor yang mempengaruhi hasil panen, seperti jenis tanaman yang akan ditanam. Hal itu dijelaskan dalam firman Allah sebagai berikut:

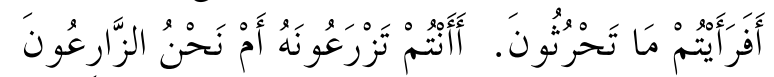

Artinya: Maka terangkanlah kepadaku tentang yang kamu tanam!. Kamukah yang menumbuhkannya ataukah Kami yang menumbuhkannya? ${ }^{24}$

Dasar hukum muzara'ah berdasarkan sunah Rasulullah terdapat perbedaan pendapat, antara lain sebagai berikut :

1. Hadits yang mengharamkan

Imam Syafi'i berpendapat bahwa haram melakukan muzara'ah karena kemungkinan buruk bisa saja terjadi saat panen. Beliau beralasan berdasarkan hadits yang diriwayatkan oleh Muslim dari Tsabit Ibn adhDhahak.

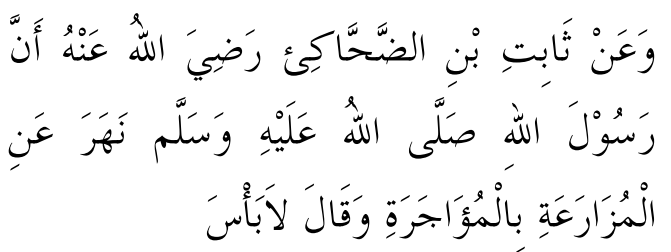

Artinya: Dari Tsabit bin Adh-Dhahak r.a bahwa sesungguhnya Rasulullah SAW melarang untuk melakukan muzara'ah, dan memerintahkan untuk melakukan mu'ajarah (sewamenyewa) saja dan Rasulullah SAW bersabda, itu tidak mengapa." (HR. Muslim). ${ }^{25}$

2. Hadits yang menghalalkan

Kerjasama dalam bentuk muzara'ah menurut kebanyakan ulama fiqh hukumnya mubah (boleh). Di antaranya adalah Abu Yusuf dan Muhammad (sahabat Imam Abu Hanifah), Imam Malik, Ahmad dan Abu Dawud Azh-Zhahiri. ${ }^{26}$ Dasar kebolehan yang digunakan para ulama dalam menetapkan hukum muzara'ah adalah sebuah hadits yang diriwayatkan oleh Bukhari dan Muslim dari Ibnu Abbas r.a.,

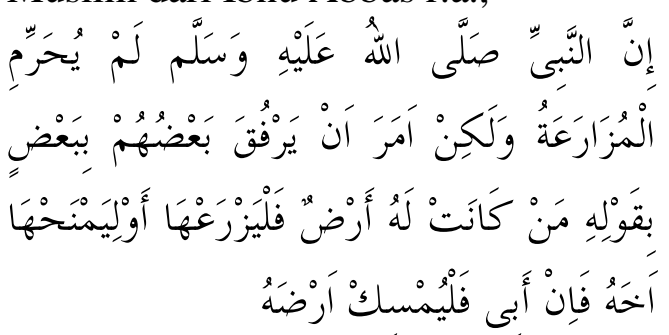

"Sesungguhnya Nabi SAW tidak mengharamkan ber-muzara'ah, bahkan beliau menyuruhnya, supaya yang sebagian menyayangi sebagian yang lain. (HR. Bukhari dan Muslim) $)^{27}$

${ }^{22}$ Abdul Rahman Ghazaly, et.al., Fiqh Muamalat (Jakarta: Kencana, 2010), 114-115.

${ }^{23}$ Sohari Sahrani dan Ru'fah Abdullah, Fikih Muamalah (Bogor: Ghalia Indonesia, 2011), 214.

${ }^{24}$ Q.S. Al-Waqiah (56): 63-64. Lihat Departemen Agama RI, al-Qur'an dan Terjemahannya: Revisi Terbaru (Semarang: CV. Asy Syifa' Semarang, 1999), 896.
${ }^{25}$ Ismail Nawawi, Fikih Muamalah: Klasik dan Kontemporer (Bogor: Ghalia Indonesia, 2012), 162.

${ }^{26}$ Rachmat Syafe'i, Fiqh Muamalah (Bandung: Pustaka Setia. 2001), 207.

${ }^{27}$ Ismail Nawawi, Fikih Muamalah: Klasik dan Kontemporer, 162. 


\section{Rukun dan Syarat Muzara'ah}

Dalam Peraturan MA RI Nomor 02 Tahun 2008 tentang Kompilasi Hukum Ekonomi Syariah pasal $211,{ }^{28}$ disebukan yang termasuk rukun muzara'ah adalah:

1) Pemilik lahan

2) Penggarap

3) Lahan yang digarap

4) Akad

Akad disini maksudnya sighat; seperti halnya ucapan seseorang yakni ucapan dengan ucapan yang setara yang disebut pernyataan ijab dan qabul, ${ }^{29}$ misalnya "saya serahkan tanah pertanian saya kepada engkau untuk digarap dan hasilnya nanti kita bagi berdua". Petani penggarap menjawab: "saya terima tanah pertanian ini untuk digarap dengan imbalan hasilnya dibagi dua". Jika hal ini telah terlaksana, maka akad ini telah sah dan mengikat. Namun, ulama Hanabilah mengatakan bahwa penerimaan (qabul) akad muzara'ah tidak perlu dengan ungkapan, tetapi boleh juga dengan tindakan, yaitu petani langsung menggarap tanah itu. $^{30}$

Adapun syarat-syarat muzara'ah adalah: ${ }^{31}$

1) Pemilik lahan harus menyerahkan lahan yang akan digarap kepada pihak yang akan menggarap.

2) Penggarap wajib memiliki keterampilan bertani dan bersedia menggarap lahan yang diterimanya.

3) Penggarap wajib memberikan keuntungan kepada pemilik lahan bila pengelolaan yang dilakukan menghasilkan keuntungan.

\footnotetext{
${ }^{28}$ Mahkamah Agung Republik Indonesia, Kompilasi Hukum Ekonomi Syariah (Bandung: Fokusmedia, 2008), 54.

${ }^{29}$ Kitab Kifayat al-Akhyar Bab Jual Beli dan Macam-macamnya dari Muamalat, 239.

${ }^{30}$ Abdul Rahman Ghazaly, et.al., Fiqh Muamalat, 115.

${ }^{31}$ Mardani, Fiqh Ekonomi Syariah: Fiqh Muamalah, 242.
}

4) Akad muzara'ah dapat dilakukan secara mutlak dan atau terbatas.

5) Jenis benih yang akan ditanam dalam muzara'ah terbatas harus dinyatakan secara pasti dalam akad, dan diketahui oleh penggarap.

6) Penggarap bebas memilih jenis benih tanaman untuk ditanam dalam akad muzara'ah mutlak.

7) Penggarap wajib memerhatikan dan mempertimbangkan kondisi lahan, keadaan cuaca, serta cara yang memungkinkan untuk mengatasinya menjelang musim tanam.

8) Penggarap wajib menjelaskan perkiraan hasil panen kepada pemilik lahan dalam akad muzara'ah mutlak.

9) Penggarap dan pemilik lahan dapat melakukan kesepakatan mengenai pembagian hasil pertanian yang akan diterima oleh masing-masing pihak.

10) Penyimpangan yang dilakukan penggarap dalam akad muzara'ah dapat mengakibatkan batalnya akad itu.

11) Seluruh hasil panen yang dilakukan oleh penggarap yang melakukan pelanggaran (penyimpangan), menjadi milik pemilik lahan.

12) Dalam hal penggarap melakukan pelanggaran, pemilik lahan dianjurkan untuk memberikan imbalan atas kerja yang telah dilakukan penggarap.

13) Penggarap berhak melanjutkan akad muzara'ah jika tanamannya belum layak dipanen, meskipun pemilik lahan telah meninggal dunia.

14) Ahli waris pemilik lahan wajib melanjutkan kerja sama muzara'ah yang dilakukan pihak yang meninggal, sebelum tanaman pihak penggarap bisa dipanen.

15) Hak penggarap lahan dapat dipindahkan dengan cara diwariskan bila penggarap meninggal dunia, sampai tanamannya bisa dipanen.

16) Ahli waris penggarap berhak untuk meneruskan atau membatalkan akad 
muzara'ah yang dilakukan oleh pihak yang meninggal.

\section{Bentuk-bentuk Muzara'ah}

Menurut Abu Yusuf dan Muhammad, bentuk muzara'ah ada empat macam. Satu di antara tiga macam tersebut hukumnya batal atau fasid, selebihnya hukumnya sah. Bentuk-bentuknya sebagai berikut: ${ }^{32}$

a) Tanah dan bibit (benih) dari satu pihak, sedangkan pekerjaan dan alatalat untuk bercocok tanam dari pihak lain. Dalam bentuk yang pertama ini hukumnya mubah, dan status pemilik tanah sebagai penyewa terhadap tenaga penggarap dan benih dari pemilik tanah, sedangkan alat ikut kepada penggarap.

b) Tanah disediakan oleh satu pihak, sedangkan alat, benih dan tenaga (pekerjaan) dari pihak lain. Dalam bentuk yang kedua ini hukumnya juga mubah, dan status pemilik tanah sebagai penyewa terhadap penggarap dengan imbalan sebagian hasilnya.

c) Tanah, alat dan benih disediakan oleh satu pihak (pemilik tanah), sedangkan tenaga (pekerjaan) dari pihak lain (penggarap). dalam bentuk yang ketiga ini hukumnya juga mubah, dan status pemilik tanah sebagai penyewa terhadap penggarap dengan imbalan sebagian hasilnya.

d) Tanah dan alat disediakan oleh satu pihak (pemilik tanah), sedangkan benih dan pekerjaan oleh pihak lain (penggarap). dalam bentuk keempat ini menurut Zhahir riwayat, muzara'ah hukumnya menjadi fasid. Hal ini dikarenakan jika akad itu dianggap sebagai menyewa tanah maka disyaratkan alat cocok tanam dari pemilik tanah menyebabkan sewa-menyewa menjadi fasid. Sebab tidak mungkin alat ikut kepada tanah karena keduanya berbeda manfaatnya. 400-401.
Demikian pula apabila akadnya dianggap menyewa tenaga penggarap maka disyaratkannya benih harus dari penggarap, menyebabkan ijarah menjadi fasid, sebab benih tidak ikut kepada 'amil (penggarap) melainkan kepada pemilik tanah.

\section{Bagi Hasil Muzara'ah}

Bagi hasil menurut bahasa adalah transaksi pengolahan bumi dengan (upah) sebagian hasil yang keluar daripadanya. Pembagian hasil seperti itu dikaitkan dengan praktek muzara'ah, dengan kata lain disebut bagi hasil pertanian. ${ }^{33}$

Diriwayatkan oleh Bukhari dari Jabir yang mengatakan bahwa bangsa Arab senantiasa mengolah tanahnya secara muzara'ah dengan rasio bagi hasil $1 / 3: 2 / 3$, $1 / 4: 3 / 4,1 / 2: 1 / 2$, maka Rasulullah SAW pun bersabda:

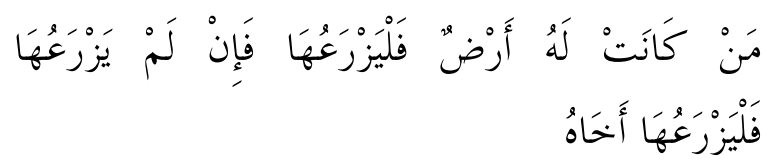

Artinya: Barangsiapa yang mempunyai tanah, hendaklah ia menanaminya atau hendaklah ia menyuruh saudaranya untuk menanaminya. ${ }^{34}$ (Hadits Riwayat Bukhari)

\section{Berakhirnya Akad Muzara'ah}

a) Masa perjanjian muzara'ah telah habis, misalnya tanaman telah selesai dipanen.

b) Meninggalnya salah satu pihak, baik meninggalnya sebelum dimulainya penggarapan maupun sesudahnya, baik buahnya sudah bisa dipanen atau belum. Pendapat ini dikemukakan oleh Hanafiyah dan Hanabilah. Akan tetapi menurut Malikiyah dan Syafi'iyah, muzara'ah tidak berakhir

\footnotetext{
${ }^{33}$ Sayyid Sabiq, Fikih Sunnah, Jilid 12 (Bandung: Alma'arif, 1998), 146.

${ }^{34}$ Mardani, Fiqh Ekonomi Syariah: Fiqh Muamalah, 240.
} 
karena meninggalnya salah satu pihak yang melakukan akad.

c) Adanya udzur atau alasan, baik dari pemilik tanah maupun dari penggarap, misalnya pemilik tanah mempunyai hutang yang besar sehingga tanah harus dijual, penggarap sakit atau jihad fii sabilillah, sehingga ia tidak bisa mengelola (menggarap) tanah tersebut. ${ }^{35}$

\section{Hikmah Muzara'ah}

Sistem kerjasama pertanian mempunyai manfaat sosial dan ekonomi yang sangat tinggi, di antaranya sebagai berikut: ${ }^{36}$

1) Terjadilah kerjasama antara pemilik lahan yang tidak mampu menggarap tanahnya dengan petani penggarap yang menggarap tanah yang bukan miliknya agar saling memenuhi kebutuhan sosial ekonominya dalam memberdayakan lahan pertanian dengan tujuan saling menguntungkan.

2) Dan menimbulkan adanya rasa keadilan dan keseimbangan. ${ }^{37}$

\section{Pertanian Padi}

Padi merupakan tanaman yang membutuhkan air cukup banyak untuk hidupnya. Tanaman ini cocok ditanam di lokasi tergenang, biasanya padi ditanam di sawah. Meskipun demikian, padi juga dapat diusahakan ditanam di lahan kering atau ladang. Hal tersebut diistilahkan dengan padi gogo. Namun, kebutuhan airnya pun tetap harus terpenuhi. ${ }^{38}$ Tanaman padi ini tumbuh di daerah tropis/sub tropis pada $45^{\circ}$ LU $-45^{\circ}$ LS dengan cuaca panas dan kelembapan tinggi dengan musim hujan 4

\footnotetext{
${ }^{35}$ Ahmad Wardi Muslich, Fiqh Muamalat, 403-404.

${ }^{36}$ Ismail Nawawi, Fikih Muamalah: Klasik dan Kontemporer, 164-169.

${ }^{37}$ Sohari Sahrani dan Ru'fah Abdullah, Fikih Muamalah, 215.

${ }^{38}$ Muhajir Utomo dan Nazaruddin, Bertanam Padi Sawah Tanpa Olah Tanah (Jakarta: Penebar Swadaya, 1996), 8.
}

bulan. Padi dapat ditanam di musim hujan atau kemarau. ${ }^{39}$

\section{PEMBAHASAN DAN DISKUSI Akad Muzara'ah Pertanian Padi di Desa Gebang Kulon Cirebon}

Orang yang berakad adalah pemilik lahan yang mempunyai lahan pertanian dan penggarap yang memiliki kemampuan menggarap sawah. Kedua pihak saling bertatap muka dan berada di satu tempat secara bersamaan melakukan perjanjian karena mereka adalah rukun dalam akad. Syarat sah terpenuhinya akad yang dimiliki masing-masing pihak sudah sesuai. Melihat kondisi yang terjadi di Gebang Kulon, dalam perjanjian kerjasama muzara'ah merujuk pada buku yang ditulis oleh Ahmad Wardi Muslich, ${ }^{40}$ bahwa rukun dan syarat yang harus dipenuhi adalah adanya pemilik lahan dan petani penggarap, sesuatu yang menjadi objek akad yaitu manfaat dari tanah yang digarap dan pekerjaan penggarap, serta berlangsungnya akad yang meliputi ijab dan qabul.

Kerjasama muzara'ah yang dilakukan masyarakat Gebang Kulon dengan secara lisan/tatap muka. Maksudnya adalah mereka melakukannya dengan mengucapkan pernyataan tawaran/penyerahan dan penerimaan/persetujuan. Pernyataan tersebut merupakan sighat akad yakni ijab dan qabul dari pihak pertama yaitu pemilik lahan, menawarkan/memberikan lahan miliknya kepada pihak kedua yaitu penggarap untuk bersedia menggarap sawah miliknya dengan menyebutkan spesifikasi lahan dan tanaman yang akan ditanam. Serta memberikan modal berupa bibit/benih tanaman dan pupuk untuk proses produksinya sedangkan alat mengikuti penggarap. Dan ada yang hanya dengan pernyataan pemberian lahan untuk digarap oleh penggarap tanpa menjelaskan letak lahan dan modal yang

\footnotetext{
${ }^{39}$ FM. Nashshar, Pertanian Organik, Cet. 1 (Bandung: Dua Usaha Muda, 2009), 18.

${ }^{40}$ Ahmad Wardi Muslich, Fiqh Muamalat, 395.
} 
akan diberikan karena penggarap sudah mengetahui letaknya, namun tetap menjelaskan spesifikasi luas lahan yang dimilikinya. Satu di antara pemilik lahan ada yang didatangi oleh penggarap yang meminta atau menawarkan diri untuk menggarap lahan miliknya dengan pernyataan meminta persetujuan kepadanya dengan alasan ingin memiliki pekerjaan tambahan agar mendapatkan penghasilan daripada di rumah saja.

Pernyataan dari pihak kedua yaitu penggarap, umumnya hanya mengatakan mau saja. Lebih lanjutnya memberikan persetujuan atas tawaran dari pemilik lahan dengan pernyataan mereka menyanggupi untuk menggarap sawah karena mereka merasa memiliki kemampuan namun tidak memiliki lahan pertanian. Salah satu dari mereka ada yang mendatangi pemilik lahan untuk menawarkan tenaganya untuk menggarap sawah dengan pernyataan meminta izin dan persetujuan kepada pemilik lahan. Beberapa di antara mereka, perjanjian dilakukan dengan menghadirkan seseorang sebagai saksi mata untuk menguatkan perjanjian meskipun tidak dituangkan dalam bentuk tulisan bermaterai. Hal itu sudah menjadi kebiasaan masyarakat desa Gebang Kulon dalam melakukan perjanjian kerjasama pertanian.

Alasan masyarakat melakukan kerjasama bermacam-macam tetapi tetap pada satu tujuan utamanya yaitu saling tolong menolong. Tujuan mendapatkan manfaat dari tanah garapan merupakan bonus atau keuntungan bersama dari hasil kerja penggarap dengan ketentuan yang disepakati. Pemilik beralasan karena tidak memiliki waktu luang untuk menggarap sawahnya sendiri, tidak memiliki keterampilan dibidang penggarapan sawah, memiliki aktivitas lainnya, membantu perekonomian orang lain, dan faktor usia yang tidak lagi memungkinkan untuk bekerja. Penggarap beralasan karena memiliki kemampuan menggarap sawah tetapi tidak memiliki sawah, tidak memiliki modal banyak untuk biaya produksi sawah, sangat memerlukan pekerjaan, dan karena faktor ekonomi yang masih kurang.

Dalam akad muzara'ah, pemilik menanggung biaya modal produksi atas petani untuk proses penanaman padi. Pemilik memberikan lahan pertanian seluas 1 hektar untuk ditanami padi, bibit/benih, pupuk kandang, pupuk urea, pupuk sp36, pupuk npk ponska, petroganik, pestisida/insektisida, dan pajak. Dan penggarap menanggung biaya operasional buruh tani/pekerja dihitung hok (hari orang kerja), dalam proses penanaman untuk 1 hektar sawah penggarap membutuhkan 10 orang pekerja dengan tugasnya masingmasing, macam-macam alat untuk menggarap sawah seperti, traktor, aniani/pisau kecil, sabit biasa/clurit, sabit bergerigi/arit, dan mesin pemanen padi. Biaya pengeringan, pengarungan dan pengangkutan ditanggung oleh masingmasing pihak.

Bagi hasil yang disepakati adalah setengah-setengah dengan pertimbangan biaya yang dikeluarkan masing-masing pihak. Ketika masa panen datang, penggarap memberitakan kepada pemilik untuk datang ke sawah. Sebelum hasil panen dibagi, terlebih dahulu dikurangi 1 ton dengan spesifikasi 1 kwintal untuk sistem bawon dengan perbandingan 8:1, 5 kwintal untuk pekerja, 2 kwintal untuk modal pemilik dan 2 kwintal untuk modal penggarap. Selebihnya hasil panen bersih dalam bentuk gabah padi basah yang dibagi dua antara pemilik dan penggarap dengan presentase 50:50. Kedua pihak mendapatkan hasil yang menguntungkan dari manfaat tanah garapan berupa gabah padi kering yang sudah dikarungkan masing-masing. Keuntungan dan kerugian yang dialami ditanggung bersama selama tidak ada unsur kelalaian dari salah satu pihak. Bagi hasil yang termasuk muzara'ah dilakukan sampai panen, selanjutnya bukan lagi muzara'ah tetapi ijarah karena ada upah pekerja 
sebagai biaya pengeringan, pengarungan dan pengangkutan.

Pembatalan yang dilakukan oleh pemilik lahan atas kerjasamanya dengan penggarap merupakan hal yang adil karena dalam kasus yang terjadi adanya unsur kelalaian dari pihak penggarap. Penggarap yang seharusnya mampu melaksanakan amanat atau suatu pekerjaan yang sudah diperjanjikan di awal akad, namun tidak dilakukannya dengan maksimal. Hal itu mengakibatkan kerugian bagi pemilik lahan yang sudah memberikan modal untuk produksi penanaman, karena tidak mendapatkan hasil apa-apa. Pemilik lahan memilih membatalkan dan mengakhiri perjanjian itu dengan alasan ketidakseriusan dari penggarap. Dalam Islam, akad muzara'ah akan berakhir apabila masa perjanjian muzara'ah telah habis.

Berdasarkan penjelasan diatas, penulis menyimpulkan bahwa akad muzara'ah yang terjadi di desa Gebang Kulon beberapa di antaranya memiliki permasalahan seperti yang dijelaskan sebelumnya masih belum sesuai karena pemilik lahan ada yang merasa dirugikan karena kelalaian dari petani penggarapnya sehingga memilih untuk mengakhiri perjanjian tersebut. Namun hal itu mampu diselesaikan oleh kedua pihak yang bersangkutan dengan cara yang baik tanpa adanya pertikaian yang berkelanjutan. Termasuk juga pembatalan yang dilakukan oleh pemilik lahan secara tiba-tiba ditengah pertani penggarap yang masih dalam proses penggarapan dan pemeliharaan sawah.

\section{Akad Muzara'ah Pertanian Padi di Desa Gebang Kulon Cirebon Perspektif Hukum Ekonomi Syariah \\ 1. Rukun dan Syarat}

Rukun dan syarat dalam kerjasama muzara'ah berkaitan dengan dua orang yang berakad yaitu pemilik lahan dan penggarap. Pemilik dan penggarap sudah jelas baligh dan berakal karena mampu melakukan perbuatan ataupun aktivitas yang memerlukan kemampuan dan kecakapan. Syarat yang dipenuhi oleh pemilik adalah memiliki lahan pertanian/sawah yang merupakan hak mutlak kepemilikannya dan bukan milik orang lain. Tanah tersebut diserahkan kepada penggarap untuk digarap agar menghasilkan manfaat daripadanya. Pemilik menjelaskan kepada penggarap tentang tanah miliknya berdasarkan segi luas, letak, kondisi dan kategorinya. Pemilik telah memberikan kesepakatan atas modal yang dikeluarkan olehnya, seperti benih/bibit, pupuk, pestisida dan sejenisnya pada saat akad berlangsung. Pemilik memberikan benih/bibit dengan kualitas baik, karena sangat berpengaruh pada hasil yang didapat ketika panen. Pemilik telah menjelaskan bagian atau presentase keuntungan/bagi hasil ketika masa panen datang dengan pertimbangan dan musyawarah kedua pihak.

Penggarap telah memiliki kemampuan dalam bidang pertanian yaitu menggarap sawah, tetapi tidak memiliki sawah. Penggarap menerima tanah tersebut yang diberikan kepadanya untuk digarap dengan persetujuan dan kesepakatan hasil yang akan didapat. Penggarap telah memberikan keuntungan kepada pemilik apabila masa panen datang dengan memberitahukan hasil panen yang didapat. Penggarap telah mengetahui jenis benih/bibit yang digarapnya pada saat awal perjanjian. Penggarap mengetahui kondisi tanah dengan pertimbangan luas, letak dan kategorinya serta langkah yang akan dilakukan apabila menjelang musim tanam datang. Pemilik dan penggarap melakukan kesepakatan mengenai pembagian hasil panen yang akan didapatkan oleh masing-masing pihak. 
Akad muzara'ah di Gebang Kulon dilakukan oleh pemilik lahan dan penggarap, sebagaimana dalam ketentuan Peraturan Mahkamah Agung Nomor 2 Tahun 2008 tentang Kompilasi Hukum Ekonomi Syariah yang terdapat dalam pasal $211^{41}$ bahwa "Rukun muzara'ah adalah : a) Pemilik lahan; b) Penggarap; c) Lahan yang digarap; dan d) Akad." Rukun dan syaratnya mengenai orang yang berakad, objek akad dan akadnya. Ketentuan objek akad yaitu lahan pertanian telah diketahui oleh pemilik lahan dan penggarap. Syarat pemilik memiliki lahan pertanian/sawah yang mutlak merupakan milik pribadi dan bukan milik orang lain, sehingga ia berhak atas segala yang berkaitan dengan tanah tersebut. Pihak lain adalah penggarap yang memiliki kemampuan dan keterampilan dibidang pertanian yakni menggarap sawah dengan pertimbangan kondisi tanah yang akan digarap, sebab akan berpengaruh pada hasil panen yang didapatkan. Hal itu sesuai dengan Kompilasi Hukum Ekonomi Syariah pada pasal $212^{42}$ bahwa "Pemilik lahan harus menyerahkan lahan yang akan digarap kepada pihak yang akan menggarap." dan pasal $213^{43}$ bahwa "Penggarap wajib memiliki keterampilan bertani dan bersedia menggarap lahan yang diterimanya".

\section{Sighat Akad}

Akad atau perjanjian yang dipraktikkan adalah kesepakatan antara pemilik lahan dan penggarap termasuk rukun muzara'ah dalam pasal 211 yang sudah disebutkan sebelumnya.

\footnotetext{
${ }^{41}$ Mahkamah Agung Republik Indonesia, Kompilasi Hukum Ekonomi Syariah, 54.

${ }^{42}$ Mahkamah Agung Republik Indonesia, Kompilasi Hukum Ekonomi Syariah, 54.

${ }^{43}$ Mahkamah Agung Republik Indonesia, Kompilasi Hukum Ekonomi Syariah, 54.
}

Kesepakatan keduanya adalah pernyataan menyerahkan dan menerima objek yang ada pada saat akad yaitu lahan pertanian yang mutlak milik pemilik lahan yang diberikan kepada penggarap untuk digarap. Ketentuan jenis benih ditentukan oleh pemilik dan penggarap melihat kondisi lahan, dan yang mempengaruhi lahan yaitu cuaca, luas tanah dan air. Faktor cuaca berpengaruh pada hasil panen, klasifikasi lahan yang terletak di daerah tropis/sub tropis apabila musim penghujan tanaman padi cocok untuk masa penanamannya. Karena padi sawah dalam pertumbuhannya ditanam memerlukan air. Padi dapat ditanam dalam kurun waktu musim hujan 4 bulan dengan kondisi cuaca panas dan kelembapan tinggi, padi juga bisa ditanam pada musim kemarau dengan paparan sinar matahari secara langsung. Sebagaimana dijelaskan dalam buku yang ditulis oleh F.M. Nashshar ${ }^{44}$, bahwa musim hujan yang terusmenerus bahkan sampai terjadi banjir merupakan keadaan yang sulit untuk menanam padi, meskipun padi ditanam dalam genangan air tetapi apabila melebihi kadar volumenya akan menyebabkan tanaman menjadi rusak dan mati. Angin juga berpengaruh dalam proses penanaman padi, apabila angin terlalu kencang maka padi akan roboh. Faktor cuaca memang tidak bisa ditebak begitu saja, tetapi penggarap selalu melakukan perawatan dengan baik.

Faktor ketegori lahan, dalam 1 hektar sawah kondisinya tanahnya baik dan subur, dekat dengan pengairan. Umumnya dikategorikan dalam tingkat I dan II, lahan yang luas berpengaruh terhadap banyaknya hasil panen apabila proses penanamannya bagus dan sesuai. Lahan yang ditanami bibit/benih padi dengan kualitas super akan berpotensi

${ }^{44}$ FM. Nashshar, Pertanian Organik, 18. 
lebih optimal dalam proses produksinya. Kesesuaian antara komoditas dengan kondisi lahan akan mengurangi biaya yang tinggi. Dan faktor air, proses penanaman padi dikatakan akan terhambat oleh terlalu banyaknya air. Agar hasil yang didapat maksimal, kadar air disesuaikan dengan tanamannya. Hal itu berdasarkan adat kebiasaan yang terjadi di Gebang Kulon. Hal tersebut terdapat pada pasal $215^{45}$ ayat (2) bahwa "Jenis benih yang akan ditanam dalam muzara'ah terbatas harus dinyatakan secara pasti dalam akad, dan diketahui oleh penggarap." Dan ayat (4) bahwa "Penggarap wajib memperhatikan dan mempertimbangkan kondisi lahan, keadaan cuaca, serta cara yang memungkinkan untuk mengatasinya menjelang musim tanam." Ketentuan pemilik dan penggarap saling sepakat dan telah mengetahui dan mempertimbangkannya bahwa jenis benih harus diketahui penggarap dan mempertimbangakan hal-hal yang mempengaruhi kondisi lahan.

Selain sepakat dengan ketentuan jenis benih yang ditanam, pemilik dan penggarap melakukan perjanjian dengan ditentukan perbuatan yang tidak boleh dilakukan baik bagi pemilik lahan maupun penggarap. Pada umumnya, pemilik lahan dilarang menyerahkan tanah yang bukan miliknya untuk dijadikan objek akad, tidak boleh menjual tanahnya ketika masa kerjasama muzara'ah masih berlangsung, dan tidak boleh membatalkan sepihak lalu mengganti penggarap yang lain tanpa alasan yang jelas. Penggarap dilarang menjual hasil panen yang belum dibagi dua tanpa sepengetahuan dan seizin pemilik, tidak boleh melakukan penyimpangan seperti lalai dalam proses penanaman padi,

\footnotetext{
${ }^{45}$ Mahkamah Agung Republik Indonesia, Kompilasi Hukum Ekonomi Syariah, 54-55.
}

tidak boleh menyembunyikan hasil panen yang didapat, tidak boleh membatalkan akad tanpa alasan yang jelas, dan tidak boleh melakukan kerjasama dengan pemilik lain saat masa muzara'ah masih berlangsung. Ketentuan tersebut ada dalam pasal 218 ayat $(1)^{46}$ bahwa "Penyimpangan yang dilakukan penggarap dalam akad muzara'ah, dapat mengakibatkan batalnya akad itu".

\section{Bagi Hasil}

Bagi hasil telah disepakati pada saat akad berlangsung antara pemilik lahan dan penggarap. Pemilik mensyaratkan hasil yang dibagi setengah-setengah dengan modal produksi disediakan olehnya sedangkan alat untuk menggarap disediakan oleh penggarap. Sebagaimana dalam pasal $217^{47}$ bahwa "Penggarap dan pemilik lahan dapat melakukan kesepakatan mengenai pembagian hasil pertanian yang akan diterima oleh masing-masing pihak." Dengan adanya bagi hasil yang akan saling menguntungkan diantara keduanya, namun jika terjadi kerugian akan ditanggung bersama dengan syarat tidak ada unsur kelalaian atau penyimpangan dari salah satu pihak. Sebagaimana dalam pasal $214^{48}$ bahwa "Penggarap wajib memberikan keuntungan kepada pemilik lahan bila pengelolaan yang dilakukannya menghasilkan keuntungan." Selama masa penanaman, penggarap memaksimalkan pekerjaannya agar hasil yang didapatkan ketika panen berlimpah dan bagus. Hal itu dilakukan oleh sebagian besar penggarap untuk pertimbangan dalam memperkirakan

\footnotetext{
${ }^{46}$ Mahkamah Agung Republik Indonesia, Kompilasi Hukum Ekonomi Syariah, 55.

${ }^{47}$ Mahkamah Agung Republik Indonesia, Kompilasi Hukum Ekonomi Syariah, 55.

${ }^{48}$ Mahkamah Agung Republik Indonesia, Kompilasi Hukum Ekonomi Syariah, 54.
} 
hasil panen, disebutkan pula dalam pasal $216^{49}$ bahwa "Penggarap wajib menjelaskan perkiraan hasil panen kepada pemilik lahan dalam akad muzara'ah mutlak".

\section{Berakhirnya Akad}

Kesepakatan berakhirnya akad tidak ditentukan secara langsung, hanya saja apabila salah satu dari pemilik lahan maupun penggarap sudah tidak memungkinkan lagi melanjutkan akad dengan alasan yang dapat diterima, maka dengan musyawarah bersama akad akan berakhir. Dalam pasal $221^{50}$ bahwa "Akad muzara'ah berakhir apabila waktu yang disepakati telah berakhir." Praktek muzara'ah yang dilakukan di desa Gebang Kulon tidak ditentukan berapa lama atau kapan waktunya akan berakhir. Pemilik lahan dan petani penggarap sepakat apabila ingin mengakhiri, salah satu dari mereka memberitahukannya dengan alasan yang jelas. Adapun yang ditentukan itu dengan syarat dalam satu tahun 2 kali panen itu semakin bertambah hasilnya, itu akan melanjutkan kerjasamanya. Berakhirnya akad juga dikarenakan pembatalan secara sepihak ketika salah satu pihak melakukan kelalaian seperti hal nya dalam kasus ini yaitu petani penggarap yang tidak memperhatikan waktu kapan untuk memberikan pupuk atau melakukan perawatan terhadap tanaman. Hal tersebut murni kesalahan petani penggarap, dan pemilik lahan tidak menginginkan lagi untuk melanjutkan perjanjian tersebut. Pemilik lahan disini merasa dirugikan dan akhirnya ia memilih mengakhiri perjanjian dan melakukan perjanjian baru dengan pihak lain yang ingin

\footnotetext{
${ }^{49}$ Mahkamah Agung Republik Indonesia, Kompilasi Hukum Ekonomi Syariah, 55.

${ }^{50}$ Mahkamah Agung Republik Indonesia, Kompilasi Hukum Ekonomi Syariah, 56.
}

serius menggarap sawah miliknya. Sebagaimana dalam pasal $218^{51}$ ayat (1) bahwa "Penyimpangan yang dilakukan penggarap dalam akad muzara'ah, dapat mengakibatkan batalnya akad itu", ayat (2) bahwa "Seluruh hasil panen yang dilakukan oleh penggarap yang melakukan pelanggaran sebagaimana dalam ayat (1), menjadi milik pemilik lahan", dan ayat (3) bahwa "Dalam hal terjadi keadaan seperti pada ayat (2), pemilik lahan dianjurkan untuk memberi imbalan atas kerja yang telah dilakukan penggarap". Kasus lainnya seperti tenaga petani penggarap yang sudah tidak memungkinkan untuk menggarap sawah ataupun sedang dalam keadaan sakit, ia menyerahkan kepercayaan kepada kerabat atau anaknya untuk melanjutkan pekerjaannya. Dan pemilik lahan pun menyetujui kesepakatan tersebut, dengan begitu akad dengan petani penggarap sebelumnya telah berakhir namun telah beralih perjanjiannya dengan petani penggarap lain yang masih termasuk ahli warisnya.

Dalam pasal $220^{52}$ ayat (1) bahwa "Hak menggarap lahan dapat dipindahkan dengan cara diwariskan bila penggarap meninggal dunia, sampai tanamannya bisa dipanen", dan ayat (2) bahwa "Ahli waris penggarap berhak untuk meneruskan atau membatalkan akad muzara'ah yang dilakukan oleh pihak yang meninggal". Ketentuan tersebut dilakukan oleh ahli waris dari penggarap yang meninggal dunia sebelum panen, perjanjian tersebut dilanjutkan karena ia juga memiliki kemampuan menggarap sawah. Kemudian apabila pemilik lahan yang meninggal dunia, penggarap tetap melakukan pekerjaannya dan akad tetap

\footnotetext{
${ }^{51}$ Mahkamah Agung Republik Indonesia, Kompilasi Hukum Ekonomi Syariah, 55.

${ }^{52}$ Mahkamah Agung Republik Indonesia, Kompilasi Hukum Ekonomi Syariah, 56.
} 
dilanjutkan. Hal itu terdapat pada pasal $219^{53}$ ayat (1) bahwa "Penggarap berhak melanjutkan akad muzara'ah apabila tanamannya belum layak dipanen, meskipun pemilik lahan telah meninggal dunia", dan ayat (2) bahwa "Ahli waris pemilik lahan wajib melanjutkan kerjasama muzara'ah yang dilakukan oleh pihak yang meninggal, sebelum tanaman pihak penggarap bisa dipanen".

Kasus lain dari pemilik lahan yang sudah tidak lagi memiliki modal untuk diberikan kepada petani penggarap yang digunakan untuk biaya bibit dan pupuk, maka akad tersebut diakhiri saat itu juga dengan pernyataan musyawarah dan dibicarakan secara bersama tanpa adanya unsur paksaan. Karena hal itu merupakan keadaan yang sudah tidak memungkinkan lagi untuk melanjutkan akad atau perjanjian. Terlebih lagi kasus pemilik lahan yang menjual lahan pertanian nya karena kebutuhan yang sangat mendesak seperti biaya perawatan keluarganya yang sedang sakit. Sehingga memilih membatalkan perjanjian, namun disini petani penggarap merasa dirugikan karena ia sudah mengeluarkan tenaga namun belum mendapatkan hasilnya. Oleh karena itu, pemilik lahan memberikan upah sebagai bayaran untuk jasa tenaganya dalam proses penggarapan sawah sebelumnya. Kejadian seperti itu sudah disepakati bersama dan tidak ada yang merasa dirugikan, sesuai dengan ketentuan pasal 221 yang sudah disebutkan sebelumnya.

\section{KESIMPULAN}

Berdasarkan hasil penelitian di atas, dapat disimpulkan 2 (dua) macam, yaitu pertama, akad muzara'ah pertanian padi di desa Gebang Kulon Cirebon istilahnya maro

\footnotetext{
${ }^{53}$ Mahkamah Agung Republik Indonesia, Kompilasi Hukum Ekonomi Syariah, 55.
}

yang dilakukan oleh pemilik lahan dan petani penggarap. Akad tersebut sudah menjadi adat kebiasaan dan tradisi setempat, yakni dengan perjanjian kerjasama secara lisan sesuai kesepakatan bersama tentang penggarapan sawah yang dikerjakan oleh petani penggarap dan pembagian hasil panen. Dalam kesepakatan tersebut, bagi hasil dilakukan dengan rasio $1 / 2: 1 / 2$. Hasil tersebut dibagi rata antara pemilik lahan dan petani penggarap, dengan lahan, bibit, pupuk dan biaya produksi berasal dari pemilik lahan. Sedangkan alat, tenaga dan biaya operasional penggarapan mengikuti petani penggarap.

Dan kedua, akad muzara'ah pertanian padi di desa Gebang Kulon Cirebon dalam perspektif Hukum Ekonomi Syariah, dalam pelaksanaan tersebut dari beberapa pemilik lahan dan petani penggarap sudah sesuai dengan Peraturan Mahkamah Agung RI Nomor 02 Tahun 2008 tentang Kompilasi Hukum Ekonomi Syariah. Hal itu dilihat berdasarkan rukun dan syarat yang diterapkan oleh pemilik lahan dan penggarap dalam melakukan praktek muzara'ah, sighat yang meliputi kesepakatan dalam akad, bagi hasil antara kedua belah pihak dan masalah penyimpangan yang dilakukan penggarap yang mengakibatkan akadnya dibatalkan termasuk dalam berakhirnya akad.

\section{DAFTAR PUSTAKA}

Agus, Erick Prasetyo. "Produktivitas Kerja Petani Ditinjau Dari Sistem Muzara'ah (Studi Pada Desa Pakan Rabaa Kabupaten Solok Selatan Sumatera Barat)", Skripsi. Jakarta: Fakultas Syariah dan Hukum UIN Syarif Hidayatullah, 2008.

Ali, Muhammad Daud. Sistem Ekonomi Islam: Zakat dan Wakaf. Jakarta: UI Press, 1988.

Antonio, Muhammad Syafi'i. Bank Syariah: dari Teori ke Praktik. Jakarta: Gema Insani Press, 2001. 
Anwar, Syamsul. Hukum Perjanjian Syariah: Studi tentang Teori Akad dalam Fikih Muamalat. Jakarta: Rajawali Pers, 2010.

Bungin, Burhan. Penelitian Kualitatif: Komunikasi, Ekonomi, Kebijakan Publik, dan Ilmu Sosial Lainnya. Jakarta: Kencana, 2007.

Departemen Agama RI. Al-Qur'an dan Terjemahannya: Revisi Terbaru. Semarang: CV. Asy Syifa' Semarang, 1999.

Djaelani, Aunu Rofiq. "Teknik Pengumpulan Data dalam Penelitian Kualitatif', FPTK IKIP Semarang, Vol. XX, No. 1 (Maret 2013).

Emzir. Analisis Data: Metodologi Penelitian Kualitatif. Jakarta: Rajawali Pers, 2012.

Ghazaly, Abdul Rahman, et.al. Fiqh Muamalat. Jakarta: Kencana, 2010.

Hendri, Sony. "Sistem Bagi Hasil Perkebunan Kelapa Sawit Ditinjau Menurut Perspektif Hukum Islam (Studi Kasus di Desa Kota Garo Kecamatan Tapung Hilir Kabupaten Kampar)", Skripsi. Riau: Fakultas Syariah dan Ilmu Hukum UIN Sultan Syarif Kasim, 2013.

Mahkamah Agung Republik Indonesia. Kompilasi Hukum Ekonomi Syariah. Bandung: Fokusmedia, 2008.

Mardani. Fiqh Ekonomi Syariah: Fiqh Muamalah. Jakarta: Kencana, 2012. - Hukum Bisnis Syariah, Cet. 1 (akarta: Kencana, 2014.

Moleong, Lexy J. Metode Penelitian Kualitatif. Bandung: Remaja Rosdakarya, 2014.

Muslich, Ahmad Wardi. Fiqh Muamalat. Jakarta: Amzah, 2013.

Nashshar, FM. Pertanian Organik, Cet. 1. Bandung: Dua Usaha Muda, 2009.

Nawawi, Ismail. Fikih Muamalah: Klasik dan Kontemporer. Bogor: Ghalia Indonesia, 2012.
Poerwadaminta, WJS. Kamus Umum Bahasa Indonesia. Jakarta: Balai Pustaka, 1986.

Priyadi, Unggul dan Jannahar Saddam ashShidiqie, "Pelaksanaan Perjanjian Bagi Hasil Pertanian Lahan Sawah", Millah, Vol. XV, No. 1 (Agustus, 2015).

Rahmat, Pupu Saeful. "Penelitian Kualitatif", Equlibrium, Vol. 5 (Juni, 2009).

Sabiq, Sayyid. Fikih Sunnah, Jilid 12. Bandung: Alma'arif, 1998.

Sahrani, Sohari dan Ru'fah Abdullah. Fikih Muamalah. Bogor: Ghalia Indonesia, 2011.

Suhendi, Hendi. Fiqh Muamalah. Jakarta: Rajawali Pers, 2013.

Suryabrata, Sumadi. Metodologi Penelitian. Jakarta: PT. Raja Grafindo Persada, 1997.

Suryana. Metodologi Penelitian: Model Praktis Penelitian Kuantitatif dan Kualitatif. Bandung: Universitas Pendidikan Indonesia, 2010.

Suwartono. Dasar-dasar Metodologi Penelitian. Yogyakarta: Andi, 2014.

Syafe'i, Rachmat. Fiqh Muamalah. Bandung: Pustaka Setia, 2001.

Utomo, Muhajir dan Nazaruddin. Bertanam Padi Sawah tanpa Olah Tanah (Jakarta: Penebar Swadaya, 1996. 